Journal of Arts

Cilt / Volume 2, Sayı / Issue 1, 2019, pp. 1-15

E - ISSN: 2636-7718

URL: http://ratingacademy.com.tr/ojs/index.php/arts

DOI: $10.31566 /$ arts.2.001

Araştırma Makalesi / Research Article

\title{
EPİSTEMOLOJİK BİR PROBLEM OLARAK SANAT ESERI
}

\author{
ARTWORK AS AN EPISTEMOLOGICAL PROBLEM
}

\author{
Fatih BALCI* \\ * Dr. Öğr. Üyesi, Çanakkale Onsekiz Mart Üniversitesi, Eğitim Fakültesi, Güzel Sanatlar Eğitimi \\ Bölümü, TÜRKIYE, E-mail: balciawake@gmail.com, \\ ORCID ID: https://orcid.org/0000-0002-4025-6647
}

Geliş Tarihi: 23 Kasım 2018; Kabul Tarihi: 30 Ocak 2019

Received: 23 November 2018; Accepted: 30 January 2019

\section{$\ddot{O Z Z E T}$}

Sanat diğer disiplinler gibi çevremizi ve kendimizi anlamamızı să̆lar. Sanatı diğer etkinliklerden ayıran şey, onun varlı̆̆ kavramada kullandı̆̆ yöntem ve bize iletme biçimidir. Sanat bu anlama ve anlamlandırma işini nasıl yapmaktadır? Bu etkinliğin sonucunda bilgi ortaya çıklyorsa, çevresinin bilgisine nasıl ulaşmaktadır? Sanatın nasıl olup da gerçekliğin bilgisine ulaştı̆̆ını anlayabilmek için öncelikle bilginin ne olduğu bilmek gerekmektedir.

Modern dünyanın yaratıcıları gerçeklik üzerine yargılarımızı tartışma konusu yaptıktan sonra, bu tartışmaların sonunda bir konsensüse vartrlar: Gerçeklik üzerine bilgimiz deneyden gelecek ve aklın işlemlerinden geçip denetlenecektir. Kant bu aklın neleri yapıp neleri yapamayacağının eleştirisini yaparken iki temel yetiyi tespit eder: Gösterme yetisi ile kavramsallaştırma yetisi.

Bilgi, önce sözcenin anlaşılabilirliği ve sonra da kendisine uygun düşen durumların deneyden elde edilebilirliğiyle ile koşullanmıştır. Sanat eserinin var olma koşulu ise, duyarlık tarafindan, önceden verili hiçbir kavramsal belirlenme olmaksızın sanat yapıtının uyandırdığı her türlü yarardan bağımsız haz duygusunun ilke olarak evrensel bir konsensusa çağırıyor olmasıdır. Sanat eserinin tam bu noktada kavramsallaştırma kapasitesi ile kavrama tekabül eden bir nesneyi göz önüne getirme, gösterme yetisi arasında kaldığını söylemek gerekir. Çünkü bu ikisi arasında bir geçiş epistemolojik olarak çok mümkün görünmemektedir. Sanat eserlerinin epistemolojik perspektiften bakıldığında gerçekliğe ilişkin hiçbir şey bildirmedikleri söylenebilir.

Anahtar Kelimeler: Sanat, epistemoloji, temsil, dil, yöntem

\section{ABSTRACT}

Art, just like other disciplines, helps us understand the environment and ourselves. What separates art from other activities is its method to comprehend existence and the way it transmits it to 
us. How does art do the work of undestanding and making sense? If, at the end of this activity, knowledge emerges, how does art reach the knowledge of its environment? To be able to understand how art reaches the knowledge of reality, firstly we need to know what knowledge is.

After the creators of modern world make our judgements on reality a matter of debate, at the end they come to a consensus: Our knowledge on reality comes from experiment and goes through mental processes and gets monitored. Kant determines two competencies while criticising what this mind can and can not do: Representation and conceptualizing.

Knowledge was conditioned firstly on the intelligibility of utterance, then the obtention of corresponding conditions from experiments. The condition of presence of artwork, by sensibility, is nonfunctional pleasure bonding us togeher around the same consensus without depending on any concept beforehand. It needs to be mentioned that artwork, at this point, is stuck between its competence of coceptualizing and competence of representing an object that corresponds to a concept, because an epistemologial transition between these two points doesn't seem possible. It can be said that artwork doesn't inform us about anything in regard to reality when looked from an epistemological perspective.

Keywords: Art, epistemology, representation, language, method

\section{GíRiş}

Modernite Projesi, Aydınlanma düşünürlerinin “nesnel bilimi, evrensel ahlak ile hukuku ve kendi ayakları üzerinde duran sanatı, kendi iç mantıkları temelinde geliştirme" konusunda gösterdikleri olağanüstü bir düşünsel çabadan ibarettir. Özgür ve yaratıcı biçimde çalışan çok sayıda bireyin katkıda bulunduğu bir bilgi birikimini, insanlığın özgürleşmesi ve günlük yaşamın zenginleşmesi yolunda kullanmaktır (Harvey, 2006: 25).

Modernitenin toplumlar üzerinde dönüştürücü etkisi olmuştur. Modernite akla dayalı olarak gerçekliğe nüfuz edebileceğimizi, birbirimizle ve doğayla olan ilişkilerimizi düzenleyebileceğimizi iddia etmektedir. Modernitenin dönüştürücü etkisi dört alanda görülmüştür. Moderniteye geçişi belirleyen dört devrim, bilimsel, siyasal, kültürel, teknik ve endüstriyel devrimlerdir.(Jeanniere, 1994: 16).

Bu köklü değişim toplumun birçok alanda birden görülür. Modernleşme teknolojinin gelişmesi ve bunla bağlantılı olarak sanayileşme gibi olgular getirmekle beraber bu sanayileşmenin bir sonucu olarak kırdan kente göç gibi olguları barındırmaktadır. Modernite toplumsal hayatın maddi yanlarını böylesine kökü olarak dönüştüren teknolojik, ekonomik ve çevresel değişimleri ifade etmekle beraber aynı oranda sosyal ve kültürel yapının bütününü etkileyen dönüşümleri de içermektedir. Modernite maddi hayattaki yarattığ 1 bu değişimlerle beraber alışkanlıkları, davranışları, ilişkileri ve değerleri de değiştirmiştir.

Modernleşme bireyi, korporatif sistemin ve belirli statülerin hiyerarşik bağlarından çözen ve ilişkilerini serbestçe düzenleme imkânı veren bir ortam doğmaktadır. 18. yy. gelişmeleriyle artık hukuk, bireyi tanrının istediği varsayılan düzen içinde kalmaya zorlamamakta, toplumun hür ve eşit üyesi olarak kendi ilişkilerini düzenlemesine imkân vermektedir (Y1lmaz,1996: 25)

Modernite köklerininin bulunduğu aydınlanma hareketiyle sıkı bir bağ içinde toplumu her yönden dönüştürürken temeline bazı tartışmaları ve buradan kaynaklanan tespitleri koymuştur. Buna göre insan ve doğa gerçekliğini sadece insan aklı ve onun uyguladığı yöntemli kuşkuyla anlamak mümkündür. Aydınlanma çağı, insanın en güçlü yetisi olarak akıl ve düşünceyi kabul etmiş ve akıl ve eleştiri aracılıyla toplumun metafiziğin etkilerinden arındırılmasına için mücadele vermiştir. Modern çağın temel fikirleri ve kavramları, geleneksel bilgi yapılarının tavsiye edilmesine neden olmuştur. Modernite din, felsefe, ahlak, hukuk, tarih, 
ekonomi ve siyasetin eleştirisiyle başladı. Modernitenin ayırt edici özelliği, ortaya çıkışının özel işareti, eleştiridir. Modern çağı oluşturan her şey araştırma, yaratı ve eylemin metodu olarak, evrim, devrim, özgürlük, demokrasi eleştiriden kaynaklanmıştı (Paz, 1994: 89).

Modernite toplumsal ilişkileri, üretim ve tüketim biçimlerini, siyasal yapıları, hukuk düzenini, gerçeklik algımızı değiştirdiği gibi sanata ilişkin yargılarımızı, kalıplarımızı derinden etkilemiş/değiştirmiştir. Modernite düşüncesi, bir aydınlanma projesi olarak sürekli ve doğrusal bir ilerleme anlayışı üzerine oturmaktadır. Bu ilerlemenin, aydınlanma felsefesine göre belli bir amacı vardır; söz konusu amaç, ideal toplum düzeni olarak ifade edilmektedir (Şaylan, 1996: 18). Bu toplum düzeni ya da hayatı doğadan ve toplumsal ilişkilerden kaynaklanan korkuları ortadan kaldırmayı amaçlamıştır. Modernite bu korkuların kaynağı olarak da metafizik kültürü görmüştür. Çünkü metafizik, aklı insanın dişında bir yere konumlarken aynı zamanda insanı çaresizlik içinde bırakmaktadır. Aydınlanma bu anlamda bilinemezlikten gelen karanlığı dağıtma için aklı insana vererek, kendini, çevresini anlamasına ve böylece korkusunun kaynağı olan sorunları çözme imkânını vermiştir. Kısaca modernite insana kendi kaderini belirleme imkânı olduğunu söylemektedir. Bu yolda toplumsal ilişkiler, kurumlar, disiplinler, bilgi sistemleri tekrar ele alınarak yeniden kurgulanmıştır. Bu toplumsal düzenin kurulması için bilim, felsefe olduğu kadar sanat da gözden geçirilerek yeniden tanımlanmış ve bu üç disipline de modern hayatın kurulmasında görev verilmiştir.

\section{SANATIN YENIDEN TANIMLANMASI}

Modernite her şeyi olduğu gibi sanatı da yeniden tanımlamıştır. Buna göre sanat antik dönemlerden 18. Yüzyıla dek günümüzdeki anlam ve işlevine sahip değildi. Kısaca baştan söylemek gerekirse sanat modernite içinde entelektüel bir faaliyete dönüşerek gerçekliği anlamamızda diğer disiplinlerin yanında yerini aldı. Bu anlamıyla sanat artık bir tür bilgilenme biçimi ve toplumun, insanın yeniden inşasında bir yola dönüşmüştür.

Antik dönemde "Sanat" teriminin Yunanca karş1lı̆̆1 (tekhnē) "güzel sanatlar" deyişindeki sanat'a karşıllı gelmez. Bu terim bizim bugün zanaat, el sanatı ve bilimle ilişkilendirdiğimiz türden insani faaliyete tekabül eder (Shiner,2004:23).

Modern estetiğin öteki asal kavramı olan güzellik ise antik düşünce ve literatürde günümüzde sahip olduğu çağrışımlara sahip değildir. Güzellik kavramı antik dönemde hiçbir şekilde yararlı ve iyi olandan ayrılmamıştır. Platon Şölen ve Phaidros adlı yapıtlarında güzelliği tartışırken yalnızca insanların fiziksel güzelliklerini değil manevi güzelliklerini, güzel huylarını, güzel algılayışlarını da kasteder. Sanat yapıtlarını ise güzellik bağlamında hiçbir yerde, hiçbir şekilde ele almaz.( Kristeller, 1965;1980:4-5) .

Antik dönemde bizim sanata ilişkin yaptığımız sınıflandırmalar da geçerli değildir. Sanatçı ameli, yani el ile çalışan insanların gurubundadır ve bedenen çalışmak zorunda olmayan soylu sınıflarla karşılaştırmak bile mümkün değildir. Bugün bizim zanaat ve zanaatçı olarak adlandırdığımız şeye çok yakındır.

18. yüzy1l modern sanat sisteminin kurulduğu ve estetik denilen felsefi disiplinin de tanımlandığı dönemdir. A. Baumgarten 1750 yılında yayınladığı Aesthetica adlı yapıtıyla, ilk kez böyle bir bilimi temellendirir. Aesthetica'nın ilk sözlerinde Baumgarten, estetiği şöyle tanımlar: Özgür sanatlar teorisi, aşağı bilgi teorisi güzel üzerine düşünme ve akla benzer bir yeti bilimi. Bu tanımlama da estetiğin ilk tanımıdır. Bu tanımın temelinde estetiğin duyusal bir bilgi olduğu anlayışı yatar. Bu duyusallık kavramından Baumgarten açık ve seçik olmayan tasavvurları anlar. Estetik açık ve seçik olmayan bulanık bir bilgidir. Açık ve seçiklik zihni bilginin ölçüsüdür. Estetik zihnin değil duyuların tasavvurunun bilimidir. Zihni tasavvurları inceleyen bilim dalına mantık, duyusal tasavvurları inceleyen bilim dalına da estetik demektedir Baumgarten (Şimşek,2014: 330-331) . 
A. Baumgarten her ne kadar sanata ilişkin bu bilgiyi açık seçik olmayan bir bilgi olarak görse de artık sanat bilgi alanı içinde görülmektedir.

Mantık ve estetik özce birbirlerinden farklı olmasa da biri zihni bilginin yetkinliğini, diğeri ise duyulur bilginin yetkinliğini arar. Yetkinlik her ne kadar hem mantığın hem de estetiğin ereği ise de, mantıksal yetkinlik ile duyusal yetkinlik aynı şey değildir. Mantığın aradığı yetkinlik zihnin nesnelere uygunluğudur. Estetiğin aradığı uygunluk ise güzelliktir. Estetik bilginin yetkinliği yine doğruluktur ama bu doğruluk estetik alanına girince güzellik adını almaktadır (Tunalı, 1984: 15).

Estetik, 18. Yüzyıl da kurulmuş olan modern sanat sisteminin felsefi ifadesidir. Bu anlamda sanata ilişskin kavrayışlarımızı ondan beklentilerimizi yansıtmaktadır. Estetiğin ortaya çıkışı geçmiş dönemde kabul edilmiş olan beğeni düşüncesinin tartışmalar sonucunda dönüşmesi dönüştürülmesi sonucu gerçekleşmiştir. $\mathrm{Bu}$ dönemde ortaya çıkan estetiğin unsurları şunlardan oluşmaktadır: Eski beğeni düşüncesinin üç ana unsuru modern estetik düşüncesine dönüştü: (1) Güzellikten alınan sıradan zevk özel bir zevk türü haline gelerek entelektüel zevke doğru gelişti, (2) ön yarg1 içermeyen yargılama düşüncesi tarafsız derin düşünce idealine dönüştü ve (3) güzellik kaygısının yerini önce yücelik kavramı ve en sonunda yaratım olarak kendine yeten sanat eseri düşüncesi alıyordu (Shiner, 2004: 220).

Bu üç unsurdan en önemlisi incelmiş zevk düşüncesidir. Eski sanat sisteminde zevk de bir araç olarak algılanmaktaydı; insanın sağlığını ve toplumsal barışı koruyan bir zevk. Ama 18.yüzyılda çıkan ayrım uyarınca sıradan ve bayağı zevklerle sanat zevki ayrılmaktaydı. Sanat daha derin ve düşünsel zevkin aracıydı. Aslında bu durum kibar sınıfların geniş halk kesimleri ile aralarına koydukları mesafenin bir yansımasıdır ve bu kesimler zaten popüler kültüre bulaşmama ve hayal gücünün daha incelmiş zevkleri karşısında popüler kültürü aşağılamada ifadesini bulmaktaydı. Kibar beğeninin incelmiş zevkleri bundan sonra psikolojik ve felsefi analizlerin nesnesi olmuştur. Daha önce fayda ve eğlenceye dayanan sanat daha sonra estetik adını alan özel bir zevk türüne dönüşmüştür. Eski beğeni ve estetik arasındaki fark şudur: Beğeni her zaman toplumsal bir kavramdır ve yeme içme giyim kuşam, hal ve tavırlarla da alakalıdır. Beğeninin birincil anlamı olan tat alma, dokunma ve koku duyularıyla da ilişkilidir. Ama yeni sanat sisteminde ve estetik düşüncesinde, koklama, tatma ve dokunma aşağı bedensel duyular olarak ayrılmıştır. Estetik düşüncesi için asıl olan görme ve duyma duyularıdır. Yeni sistem beğeni kavramını sıradan tensel zevklerden ve faydanın getirdiği tatminden ayırmaya çalışıyordu. Estetik beğeni daha entelektüel bir beğeniydi. Pek çok yazar o dönemde beğeniye dair zevkin adeta ayrı bir meleke olduğunu, "zihin gözü", “ iç duyu" "altıncı his" olduğunu söylüyordu (Shiner, 2004: 221).

"Sanat" kavramının oluşması 18 yy. da sanata ilişkin bazı düşüncelerin netleşmesiyle gerçekleşmişti. Buna göre sanat eğlenme, oyalanma, kendisiyle hedeflenen pratik faydaları hoş bir şekilde karşılayan bir araç olmaktan çıkmış, daha yüksek ve düşünsel zevkleri sağlayan bir zihin gözü, iç duyuya dönüşmüştür. Sanat kontrolsüz, doğrudan ve yoğun bir duygulanımdan Diderot'un betimlediği karşılaştırma yetisini zedelemeyen daha sakin ve düşünceli bir duygusallığa geçiyordu. $\mathrm{Bu} 18$. yüzyılda adlandırılmaya başlandığı gibi “estetik" tavırdı. Estetik tavır yoğun bir duygusallık ile entelektüel konsantrasyonu birleştirilmesini öneriyordu (Shiner, 2004: 220-228).

$\mathrm{Bu}$ izlekte devam eden modernite sanatı entelektüel bir faaliyet olarak, toplumun ve insanın inşası için göreve koşmuştur. Bugün kabul edilmiş bir üçlü olan bilim, felsefe ve sanat bu görevin gerçekleştirilmesi için birbirlerinin tamamlayıcısı olarak iş göreceklerdir. 


\section{MODERN EPİSTEMOLOJI VE SANATIN TARTIŞMALI KONUMU}

Bilindiği üzere, en genel anlamıyla epistemoloji, felsefenin; bilginin kaynağı, doğası, doğruluğu ve sınırlarını araştıran dalına gönderme yapmaktadır. Bu anlam çerçevesinde olmak üzere, epistemolojide, gerek bilginin oluşumu, gerekse bilgi iddialarının geçerliliği noktasında, öteden beri oldukça ciddi tartışmalar yapılagelmiştir. Örneğin Sofistler, her şeyin oluş içerisinde olmasından ve oluşun da sabitlenmeye müsait bir karakter arz etmemesinden hareketle, her türlü bilgi iddiasının geçersizliği/rölatifliği üzerine vurgu yapmışken, Sokratik rasyonalizmin vücut verdiği Batı metafizik geleneği, düşünen bir varlık olarak tanımladığ insanın, değişmenin arkasındaki öze, söz konusu düşünebilme yetisiyle ulaşabileceğini ve dolayısıyla da evrensel, tarihdışı bilgi iddialarında bulunabileceğini varsaymıştır (Küçükalp, 2003: 85).

Rasyonalist yaklaşımlar bunu, insan aklının doğuştan getirdiği hakikatlere müracaatla, yani düşüncenin kategorilerinin varlığın kategorilerine tekabül ettiği, dolayısıyla da insanın akla referansla gerçekliği teorileştirebilmeye muktedir olduğu fikrinden hareketle izah etmeye çalışırken; empirist yaklaşımlar ise bunu, insan zihninin gerçekte boş bir levha olduğu, gerçekliğin duyumlarımız yoluyla zihnimize yazıldığı, akıl yürütmenin de söz konusu duyumların birbiriyle ilişkiye sokulmasından başka bir şey olmadığı şeklindeki düşüncelere referansla izah etmeye çalışır. Bilginin kaynağı konusunda aralarındaki ihtilafa karşın, modernizmin iki temel epistemolojisi konumunda bulunan rasyonalizm ve empirizm, aslında, "gerçeklik"in "olan bir şey" olduğu konusunda bir mutabakat içerisindedir. Rasyonalistlere göre, bu, olan şey, insanın evrensel, tarihdışı niteliğine işaret eden soyut akla içkin iken, empiristlere göre, bilimsel bir yöntemle bilgisine ulaşılabilen, insanın dişında olgusal bir şeydir. Kaynağı ister akla, isterse deney ve gözleme dayandırılsın, her iki epistemolojinin de paylaştıkları ortak nokta, bilgi ile gerçeklik arasındaki ilişkinin bir denklik, ya da temsil ilişkisi olduğudur.( Küçükalp, 2003:91).

Bu denklik ya da temsil ilişkisi iki yolla anlaşılabilir ya da ele alınabilir. Birincisi yöntem ikincisi ise bu temsilin ortaya çıktığı dil zeminidir.

Modern bilimin başlangıcı olan dönemde aklı referans alan ve yöntemi kullanan bilincin yunan felsefesi merkezli doğa algısını reddettiğini, yeni bir paradigma ortaya koyduğunu bunun sonucunda dönemin "yöntem çă̆ı" veya "bilim çă̆ı" olarak adlandırıldığını görmekteyiz. Burada dikkatimizi çeken en önemli nokta bilim ve yöntem kavramlarının birbirinden ayrılamaz olduğu inancının yerleşmiş olması ve bilimsel yöntem anlayışının iyice oturmaya başlamasıdır. Bu doğrultuda 17. yy. bilimsel yönteminin ayırt edici çizgisi bir kuramın açıklamak istediği gözlenmiş olgulara nasıl bağlanması gerektiğine ilişkin anlayışı, kuramlar oluşturmak ve onları deneysel sınamalara bağlı kılmak için kullandığı mantıksal adımlar dizisiydi. Deneysel yöntem adı altında oluşturulan bu tümevarımsal ve deneysel süreçlerin kullanılması ise 13 yy. filozoflarına kadar gitmektedir. Fakat buradan itibaren doğa bilimlerinin oluşumu sadece gözleme ve betimlemeye indirgenemeyecek kadar çok yönlü bir gelişim aşamasından geçmiştir. Buradaki temel motivasyon olan metin üzerinden düşünme, anlama ve çıkarsama refleksiyonun yerine doğrudan somut verilere bakılarak bilginin yeniden inşa edilme çabası doğa bilimlerinin gelişiminin önünü açmıştır (Kahraman,2017:229).

Gerçeği araştırmak ve bulmak için iki yol olduğunu düşünen Bacon'a göre "Birincisi, en genel önermelere ulaşmak için duyulardan ve özel olaylardan yola çıkar ve bu ilkelere ve değişmez olduğu var sayılan gerçeklere dayanarak ara önermeleri bulur ve değerlendirir, genelde izlenilen bu yoldur. Aynı şekilde duyulardan ve özel olaylardan çıkan diğeri, sonunda en genellerine ulaşmak için sürekli ve artan bir biçimde ilerleyerek buradan önermeleri çıkarır. Ona göre bu gerçek yoldur ama bunu kimse hâlâ denememiştir. 
Bacon'ın gerçek yol olarak değerlendirdiği "varlığa boyun eğdirme"nin kuramsal zeminini oluşturan bu yöntemsel yapı yine belirli akıl yürütmelere kendisini dayandırmaktadır. Bacon, zihne uygulanacak araçlar yoluyla anlamanın harekete geçeceğine ve korunacağına inanır. Şüphesiz Bacon'ın bu araçtan kastettiği şey yöntemdir. Bu yöntemi ise o, tümevarım olarak görmektedir. Bacon'a göre insanları tikellere ve tikellerin düzenli serilerine ve sıralarına yöneltmeliyiz ve insanlar sahip oldukları kavramları bırakıp şeyleri tanımaya başlamalıdırlar. Buna göre biz öncelikle olanaklı olduğu ölçüde tek tek şeylerle tanışacağız, bundan sonra da genel olarak "şey" in ne olduğunu bileceğiz (Kahraman, 2017:234-235).

Bilgi ile gerçeklik arasındaki temsil ilişkisi en keskin ifadesini, büyük ölçüde empirist epistemolojiden beslenen ve modern bilim düşüncesinin de özünü oluşturan pozitivist ve mantıkçı pozitivist yaklaşımlarda bulmuştur. Bilim adamının, her türlü öznel yargısını araştırmasının dışında bırakabileceği ve bu şekilde, dışındaki nesnel gerçekliği teorileştirebileceği iddiasındaki pozitivistler, deney ve gözlem dışındaki bütün bilgi kaynaklarını reddetmişlerdir. Benzer bir şekilde, mantıkçı pozitivistler de, olgusal ve mantıksal gerçeklik dışındaki bütün gerçeklik iddialarının geçersiz/anlamsız olduğundan hareketle, pozitivistlerin nesnel bilgi arayışlarına paralel olarak, olgusal ve mantıksal gerçekliği temsil etme iddiasındaki nesnel bir dil arayışı içerisinde olmuşlardır (Kasım Küçükalp, 2003:91-91).

Batı düşün dünyasının köklerinde var olan ve zamanla şekil değiştirdiği halde kaybolmayan bu düş bulunur. Bu düş, dünyayı tam olarak temsil edecek mükemmel ussallıkta bir dil yaratma isteğidir. Böyle bir akıl dili, dünyadan, gerçeklikten tam olarak söz edebilecektir. Kurucusu Platon'dan başlayıp Aristoteles, Kant ve Hegel'den geçerek Wittgenstein ve Heidegger e uzanan felsefe tarihi içinde söz merkezci bir arayış olmuştur. Söz merkezcilik dünyayı tam olarak yansıtabilecek ya da temsil edebilecek bir dil ister. Bu dilin arayışı batı düşün dünyasının sürekli peşinde koştuğu bir ödevdir. Aydınlanma düşüncesinin mimarlarından Descartes bu dilin kurulmasında matematikten yararlanılması gerektiğini söylemektedir. Bunun nedeni ise matematiğin evrensel ve kesin bir yapısının olmasıdır.

Aydınlanma düşünmenin ve dolayısıyla sözün sınırlarını sürekli çizmek istemektedir. Bunun en uç örneği Wittgeinstein'in Tractatusunda görürüz. Wittgeinstein'in özellikle Tractatusu'da çözmeye çalıştı̆̆ı sorular nelerdi, sorusuna Quinton şu yanıtı veriyor: Temel sorunun şöyle özetlenebileceğini sanıyorum: Dilin varoluşunu sağlayan şey, dilin olanağ nedir? Dili, Wittgenstein'in onun en önemli amacı saydığı amaç için, yani dünyayı betimleme, olguları dile getirme, doğruları -ya da başarısız kalındığında yanlışları- anlama amacı ile kullanmak nasıl olanaklı olabiliyor (Kahraman, 1995;77). Wittgenstein dilin düzeni ile dünyanın düzeni arasında benzer bir ilişki olduğunu söylemektedir. Dünyanın dilde temsil edilebilir olacaksa, çeşitli bir araya gelme olanaklarına sahip bir düzeni, yada dizgesi olması gerektiği görüşü vardır. Belirli bir durumda, durumun nasıl olduğu, bu nesnelerin düzenlenme biçimidir. Bunun sonucu olarak da söylemin-yani asıl önemli işlevinde kullanılan dilin özünde, anlamlı bir içeriği, dünyayı oluşturan olgular resimlemesidir (Kahraman,1995:78) Wittgeinstein'a göre dil dünyayı resmetmelidir. Dilsel bir önerme önce nesneleri resmeder, sonra nesneler arası ilişkileri betimler. Bunun dışında kalan dilsel önermeler saçmadır.

Bilimin felsefesini oluşturan mantıkçı pozitivistler de dil konusunda benzer düşünürler. Onlarda anlamlı ile anlamsızı ayırt etmek için bir önermenin doğruluğunu, o önermenin olgularla bağdaşmasıyla mümkün görürler. Sonuçta mantıkçı pozitivizm düşüncesinin önerdiği yasal bilgi çerçevesi şöylece konumlanabilir: I) Yalnızca içerikleri erişilebilir araçlarla denetlenebilen (emprik olarak doğrulanabilen) dünya hakkındaki önermeler bilgi adına hak kazanabilirler. II) Bilimlerin ve mantığın (matematiksel) kullandığı yöntemlerden başka hiçbir yasal bilgi edinme yolu yoktur. III) Hem deneyimden bağımsız olarak geçerli olabilen ve hem de olguları herhangi bir biçimde betimleyen önermeler olmaz (Altuğ, 1989:47). 
Bu o kadar böyledir ki, Wittgenstein'a göre bir düşünme mümkün olan bir durumu içerir” öyleyse 'Zeus'un sakalları uzundu türünden tümcenin kurulmasına hiç gerek yoktur; çünkü, bu tümcenin imlediği olgular gerçeklikteki herhangi bir şeye tekabül etmez, dolayısıyla anlamsızdır. Yani dil, değer üzerine konuşmaz öyleyse ahlaki ve estetik değer yargıları dilin sahici, anlamlı kullanımları sayılmazlar (Kahraman, 1985:80) .

Modern epistemolojin sanat ile ilişkisindeki kriz tam da bu noktada açığa çıkmaktadır. Böyle bir dil nitelikler, değerler, ahlaki yargılar, estetik değerler üzerine konuşmaz. Bu konularda susmak zorundadır.

\section{SANATIN YÖNTEMI}

Sanatın yöntemi felsefe ve bilim ile karşılaştırıldığında, sanatın bu iki disipline yaklaşan ve uzaklaşan yanları olduğunu görülür: Sanat bilim ve felsefe dünyanın bakan gözlere karşılık vereceğine inanmaktadır Sanat da insanın bilgi kabiliyetinin ortaya çıktığı bir alandır. Sanat bunu felsefede olduğu gibi sadece kavramsal boyutta değil, duyarlılığın zemininde de yapar. Sanatın duyusallığı onun biricik, somut ve bireysel olmasını sağlarken, bilgi yetilerimizden aldığı renk onun yasa statüsüne oturmasını da sağlar.

$\mathrm{Bu}$ yüzden sanat özne ile nesnenin geriliminde bir barış sahası, bir uzlaşım olanağı olarak görülür: Bilim öznelliği kaldırıp nesnel bir düzen çizmeye çalışırken, felsefede insanın önemini vurgulayıp durmaktadır. Bu iki eğilim sanatta kendiliğinden doyurulmuş gibidir. Güzel, özne ile nesne arasında bir işbirliği, duyular-üstü dayanakta temel bulan özgür bir “kendiliğinden uyum"dur ( Altuğ, 1989: 44).

Bütün bu tanımlamalar bizi epistemoloji sorununa ger götürmektedir: Bilgi olanaklı mıdır? Doğru bilgiye nasıl ulaşabiliriz? Bilgi akıldan mı, yoksa algıdan mı gelmektedir?

Kant salt aklın eleştirisinde anlık'ın ve us'un neleri yapıp neleri yapamayacağını araştırıp felsefenin sınırlarını çizmek ister. Kant'a göre metafiziğin ilkeleri, yani temel yargıları ve temel kavramları, hiçbir zaman deneyimden çıkarılmamalıdır. Böylece ne fizik biliminin kaynağı olan dış-deneyim ne de empirik psikolojinin temel dayanağı olan iç-deneyim metafizik bilginin temelindedir. Demek ki o, apriori olan, salt anlıktan ve salt akıldan çıkan bilgidir ( Altuğ, 1989:14).

Öte yandan bilim ise salt olguları betimlemeyi kendime temel almıştır. Bilim dış dünyanın bilgisinin tarafsız bir gözlem ve sistematik deneye dayanılarak çıkarılacağına inanır. Pozitivist düşünce tarzı "olgular"dan harekat etmektedir. Pozitivist görüşe göre olgu ve böylece "gerçek" olan, yalnızca duyusal olarak algılanabilen fenomenlerdir; yani nesnel reel gelişme süreçlerinin yüzeydeki fenomenleridir (Özügül, 1991:29).

Sanatın yöntemi bu iki yöntemle karşılaştırıldığında nasıl açıklanabilir? İlk verilecek yanıt sanatın duyusal kökenli fakat öznel bir yargı olduğudur. Sanatın duyusallığı onun tikelliğini, öznel yanı ise onu tümelliğini gösterir. Kant'ta estetik olan, tam da dolayısımsızlıkları içinde tikelleri, bir tümel yasaya, ama hiçbir anlamda formüle edilemeyecek bir yasaya bağlarken, kavramsal olanı kısa devreye uğratır. Salt ve pratik olanlarına karşıt olarak, estetik alanda, bireysel olan, tümel olana doğru soyutlanamaz, fakat tümel olanı, kendi yüzeyinde kendiliğinden bir şekilde görünüşe çıkarmak suretiyle, tam da kendi tikelliği içerisinde tümele yükselir ( Altuğ, 1989:141).

Sanat bunu nasıl yapmaktadır? Hem tikel olanı, hem de tümel bir yasayı nasıl içermektedir? Önce estetik tavrın nasıl bir tavır olduğunu açıklamakla başlayalım işe. İsmail tunalı "estetik" adlı kitabında estetik tavrı şöyle açıklıyor: İlk olarak birinci bakış tarzını ele alalım. Bu bakış tarzı, köşkün ne zaman ve kimin tarafından yaptırıldığı sorusuyla ortaya çıkıyor. Ya da üslubunun ne olduğu, sanat değerinin ne olduğu soruları ile. Bu sorular açısından 
köşke bakmak, onun hakkında tarihsel ve sanat tarihi yönünden bilgi edinmek isteyen bir bakış tarzını ya da tavır almayı gösterir. Böyle bir tavır, bilgi edinmek isteyen bir tavır, bilgisel bir tavırdır. Böyle bir tavrın belli bir ereği vardır, objeler hakkında doğru bilgiler elde etmek. Bundan ötürü böyle bir tavra düşünsel-bilgisel tavır ya da intellektüel tavır alma adı verilir. Öbür bakış tarzına köşkün parasal değerini soran bakış tarzına gelince, bu bakış tarzı pratik ekonomik bir tavır olarak adlandırılabilir. Bu bakış tarzı içinde bakanın pratik ya da ekonomik yarar gibi bir ereği vardır. Üçüncü tavra gelince: Bu bakış tarzı, yapıya, köşke hiçbir soru sormadan, salt seyretmek için yönelir, ondan hoşlanmak, ondan haz duymak için onu seyreder. Yapının ne tarihselliği ne de sanat değeri ne de ekonomik değeri v.b. sorular onu hiç ilgilendirmez.; onu, köşkü seyretmek için seyretmenin dışında hiçbir şey ilgilendirmemektedir. Böyle bir tavır almaya da estetik tavır alma adı verilir ( Tunalı, 1984: 30-37).

Bu seyretmen eyleminin anlamı ne olabilir? Epistemolojik olarak bakarsak bu tavır nasıl bir tavırdır. Tunalı yazısının devamında bu konuya değinerek şöyle söylüyor: İnsanın en temel etkinliği olan bilme etkinliğinin; şimdi ve burada olan nesnelerden kalkarak genel düşünsel biçimlere, kavramlara ulaşmak olduğunu daha Sokrates (M.Ö 569-499) ve Platon'dan (M.Ö 428-348) beri biliyoruz. Bilgisel tavır bu anlamda kavramsal tavır anlamına gelir... Bu soruyu başka türlü sorarsak, estetik tavır bir estetik haz alma tavrı olduğuna göre, acaba bu haz duymanın yöneldiğimiz objenin kavramsal yapısı ile bir ilgisi var mıdır? Bu soruya ilkin daha yalın bir yanıt ile karşılık vermek gerekir. Estetik tavır, bireysel varlıkla ya da tek tek 'burada ve şimdi' bulunan var olanlarla ile ilgilidir, genel kavramsal objelerle değil. Buna göre, estetik tavrın bir genel obje olan kavramsal yapı ile ilgili olmaması gerekir. Şöyle ki, karşımda duran henüz yeşillenmekte olan ağaca estetik olarak, haz duyarak bakıyorum., bu anlamda onu estetik olarak kavrıyorum. Böyle bir hoşlanma objesi olarak kavradığım bir ağaç, karşımda duran bireysel bir ağaçtır ( Tunalı, 1984:44-45) .

Buna göre sanatı bilgi konusu yapamayız. Bu görüş büyük ölçüde Kant'ın estetik yargı gücü konusunda yazdıklarına dayanmaktadır. Kant'a göre estetik yargı tümellik içerse de bu tümellik bir bilgi değildir. Çünkü bu tümellik yasası objeden değil özneden kaynaklanan bir yasadır. Tikel bir nesnenin güzel olduğuna dair hiçbir kural ya da yasa bulunamaz. Estetik bir yargıda, tikel bir durumu, bir kural altına koyuyormuşuz gibi, bir tümel kabulü varsaymamızdan ibarettir her şey. Estetik nesne bizim bilgi yetilerimizi özgür bir oyuna geçirecek bahanedir yalnızca. Burada nesnenin bilgisine değil öznenin kendi olanaklarının bilgisine varılır. Özne böyle bir nesneyi kavrayabileceğinin farkına varır. Bu nesne hakkında bir bilgi değil, öznenin kendisi hakkında bir bilgidir ( Altuğ, 1989).

Bu klasik teoriye göre, bilginin yolu tekil nesnelerden tümel ya da genel olana doğrudur. Bu düşüncenin kökeni Platon'a kadar dayanmaktadır. Platon bizim tümel dediğimiz varlıklara idea ya da biçim diyordu; ideaları dış dünyadaki nesnelerin sınıflandırılması olarak değil, tekil bir varlık olarak başka bir dünya da olduğuna inanıyordu. İdealar kuramına göre iki tekil adamın birbirine benzediğini bunların ikisinin de "Adam" ideasına benzerliğine bakarak saptayabiliyorduk. Ancak Platon'un “Adam” ideası tekil bir varlık olduğuna göre, dünyadaki her adamın, tekil bir varlık olan "Adam” ideasına benzediğini saptamak mümkün olmayacaktır. Platon'un "Adam" ideası tekil olduğuna göre, dünyadaki adamın "Adam" ideasına benzediğini bilebilmek için, başka bir ideaya gereksinim olacaktır ki, bu sonsuza dek böyle gider

Aristoteles tekil nesnelerden tümel yasalara geçişteki bu sorunu gayet net fark ettiği için, bizde tümeli açıkça seçme gücünün bulunduğunu söyleyerek sorunu aşmak istemiştir. Tabi ki, sorun böyle ortaya konunca tikel nesneler bilgilenmenin ilk basamağı olan duyumsama da kalacak ve tümel altına kaydırılmadığı sürece bilgi olarak tanımlanamayacaktır. Sanat da şimdi ve burada olan tikel nesneler grubunda olduğuna göre bilgi kavramı dışına atılacaktır. 
Ama pek çok düşünür için sanat geçeklik üzerine düşünmenin bir yoludur. Hatta kavramsal bilgilenmeden daha temel bir bilişe karşılık gelirler. B. Croce için estetik bir lüx etkinliği olarak, kökü gündelik hayat sezgileri içine girmiş bulunan temel bir etkinliktir. Bu sezgi bilgisi etkinliği zihni bilgi kadar, hatta ondan daha temelli ve ondan daha önce gelen bilgi etkinliğidir (Tunalı,1983:279).

Birçok düşünür sanatı kavrayış olanaklarımızdan atmak istememişler, ama onu sezgisel bir kavrayış biçimi olarak tanımlayarak, onu bir bakıma epistemoloji sorununun dışına taşımak istemişlerdir. Çünkü sezgi tanım gereği tanımlanamaz bir şeydir: Sezgi şeylerin dolaysız, yani hiçbir kanıta dayanmayan nesnel bağımlılığını gözlemlemedir ( Balc1,1993).

Bilgi teorisindeki tikel ve tümel arasındaki geçişin sanat alanında oldukça sıkıntılı olduğu bellidir. Tümeller olmadan kavramsal düşünmeden söz etmek ve bilgi iddiasında bunmak mümkün olmayacağına göre bu sorunun çözülmesi ya da ortaya konulması gerekir.

Bunun için Spinoza'nın bilgi süreciyle ilgili söylediklerine bakmak faydalı olabilir. Spinoza her tanımlamanın bir olumsuzlama olduğunu söylemişti. Yani bir şeyin sarı olduğunu söylemek, onu sarı olmayan şeylerden ayırmak, bir bakıma onun sarı-değil olmadığını söylemektir. Böylece, söylediğimiz ya da düşündüğümüz ya da davranışlarımızda etkisi altında bulunduğumuz ilk bilgi, dünyadaki nesnelerin ikiye ayrılmasıyla ortaya çıkacak demektir (Hacıkadiroğlu,1985.154). Demek ki bilgimiz her zaman en genel olandan tikele doğru uzanır ve bir nesneyi tanımlarken nesnenin sınıflandırmasının bir ara aşamasını söylemekteyizdir. Böylece klasik deneyci felsefenin, dünyayla ilk ilişkimizi tikel nesnelerle kurduğumuz ve onların bilgisini edindikten sonra, bunlar üzerinde yaptığımız bir takım işlemlerle tümellere ulaştığımız yolundaki görüşün kabul edilebilir olmadığı anlaşılmaktadır. Bergson nesnelerin kendi başlarına başka şeylerden bağımsız olarak ele alınması algılama için bir lükstür der. Şurası hiçbir şüpheye yer bırakmayacak kadar açıktır ki: algılamanın temelinde bir nesnenin yapısal öğelerinin bir bütün halinde ve soyutlama şeklinde yatmaktadır. Yani algılama olgusunun kendisi aynı zamanda bir soyutlamadır. Bu ayrıca tüm kavramanın da başlangıcıdır (Genç ve Sipahioğlu, 1990: 187).

Bir nesneyi hiçbir zaman saf ve yalıtık olarak algılayamayız. Tikel bir nesne tümel altına kaydırılır. Ama eleştirel bir göz için olay burada sonlanmaz. Nesnenin duyumsanan içeriği ile tasarımı karşılaştırılır, sınamaya tutulur. Bu anlamıyla sanat gördüklerimi bir tanımlamadır ve her tanımlama gibi bir olumsuzlamadır. Fakat her olumsuzlama, olumsuzlananı da içerir. Kavram ve görüntü, Eagleton'ın "kant'ta imgesel olan" adlı makalesinde anlattığı özne ve nesneye benzemektedir: birbirlerine üstün gelme savaşı veren, ama birbirlerinin öldüren cazibesinden de vazgeçmeyip, her 1stırap dolu ayrılıktan sonra, yeniden bir kez daha denemeye karar veren birbirine zıt iki eşi anlatan bir masal gibi, özne ve nesnenin dramı, onların birleşip ayrılmalarıyla, uygun ve uygunsuz birliktelikleriyle yüklü bu anlatı, modern felsefi sahneye neden böyle ara vermeksizin hakim olmuş acaba (Eagleton, 1994:125)? Özne ve nesnenin bir türevi olan görüntü ve kavram aynı durumu yaşamaktadır. Dünyanın dildeki anısı, oluş halindeki akışkan haldeki yaşamı karşılayamaz. Kavram görünüşler dünyasını sabitlemek ister, görüntü bu sabitliği yeniden biçimlendirmek için zorlar.

Sanat duyumsanan, hissedilen gerçekliğe, biçimin içrek yapısına sürekli geri dönerek kavrayış olanaklarımızın sürekli bir değişimini, genişletilmesini de beraberinde getirir. $\mathrm{Bu}$ bilinenlerle görülenlerin karşılaştırılarak ayrıştırılmasıdır. Görülenlerle bilinenler birbirleriyle örtüşmüyorsa, bilinenlerin yeniden düzenlenmesi gerekecektir.

Sanat her ne kadar kavramsal boyutla ilişki içinde etkinliğini sürdürüyorsa da o kendini bir kavram olarak öne sürmez. O hep duyumsanan hissedilen gerçekliğin, duyumsanan, hissedilen bir imgesi olarak kendini öne koymak ister. Kavram deneyimimizin sembole 
bağlanmış bir anısı iken, sanat eseri deneyimin kendisi olarak, yaşadığımız şey olarak kendini dışsallaştırır (Balcı,2001).

\section{SANAT VE DİL İLIŞKIISI}

İnsan duygu ve düşüncelerini başkalarına iletmek için göstergeler üretir. Bu yüzden insanın ürettiği göstergeler tamamen üretilmiş, yapay göstergelerdir. Bunun dışında kalan doğal göstergeler de vardır. Doğal göstergeler, olaylar arasında doğada bulunan bağlantılara dayanır. Sanat insanın yarattığı yapay göstergeler arasında yer alır. Ama sanat tamamen dilsel yapılar gibi anlaşmalı göstergeler üzerine kurulmadığı gibi, doğal göstergeler üzerine de kurulmamıştır. Daha çok bu iki göstergenin sentezi olarak tanımlanabilir. Sanat hem doğal göstergelerden yararlanır, hem de dilsel yapılardan. Ama bunlardan farklı bir iletişim biçimidir. (Fatih Balc1,2001). Dolayısıyla “...sanat dili kavramı yerine, sanat söylemi ya da sanatsal söylem demek daha doğru bir söyleyimdir. Dil, belli kuralar içinde, olabilirliklerden seçerek var olur, dizgeseldir. Sanatsal söylem gibi dil de, genel söylem içinde yer alır. Söylem bilim diyebileceğimiz göstergebilim, dilbilimi de kapsar. Dil dışı söylemler, dilden daha bireyseldirler, daha esnek ve kuraldışı biçimlenişe daha açıktırlar. Yazı dili, tiyatro dili, resim dili, görsel dil gibi deyimlerin aslında, dilin değişik alanlarında ki biçimlenişi sanısından doğduğunu söyleyebiliriz. Yazı dili dediğimiz şey, dil etkinliğinin, ses ve sözün bir taşıyıcıya bindirilmesidir. Yazı dili yerine, yazılı dil, yazılmış dil diyebiliriz, ancak resim dili söyleyişi, resim söylemini, resimli dile, ya da dilin resimlenişine götürür ki biz buna resimleme (illistürasyon) diyoruz (Erdoğan,1990:3).

Böylece sanatın bir anlaşmalı dil olmadığını anlıyoruz. Ama aynı dillerde olduğu gibi, sanatın da kuraları, yapıları bulunmaktadır. Biz nasıl dilin içinde doğup orada yetişiyor, onun tarafından belirleniyorsak, sanatçı da böyle sanatsal göstergeler ve bunların kuralları içinde var olur. Bu olgu bazı sanatsal dönemlerde daha açık görülür. Bu dönemlerde sanatsal göstergeler dil gibi sistematikleşmiştir. Göstergelerin anlamı tamamen herkesin üstünde anlaştığ 1 şeylere dönüşmüştür. Örneğin ortaçağ sanatı böyle bir sanattır. Bu çağın sanatı bir simgeler dünyasıdır. Her rengin, biçimin önceden oluşturulmuş ve kabul edilmiş bir anlamı vardır. Hemen hemen, bu simgesel biçimlere yeni bir şey eklenmez, çıkarılmaz. Ortaçağ sanatı, eski mısır sanatı da böyle bir sanattır (Fatih Balc1,2001).

Sanatsal iletişim anlaşmalı dil yapıları gibi işlemez. Dilde iletişimi sağlayan biçimler geçmiş deneyimlerimizin bir form altında anısı olarak çalışırken; sanatta bu, geçmiş tecrübenin biçim üzerinden anımsanması değil yaşanmasıdır. Sanat sadece bir duyum değildir. Düşünme ve duyum yetileri arasındaki ilişkiden ortaya çıkar.

Bu yüzden Suzanne K. Langer'in de dediği gibi sanatsal yapıtlart izlemek bir önermeyi düşünmekten çok yeni bir deneyimde bulunmaktır. Sanatsal yapitlar ancak kendileriyle anlaşılabilirler. Onları tamamen söze dökmek mümkün değildir. Çünkü kavram deneyimin sonunda onun vekili olarak ortaya çıkar ; ve vekil aslın yerini tutmaz. " ... sanatsal hakikat denen şey, duygu biçimlerine varıncaya değin, simgenin hakikatidir- bunlar adı sanı olmayan biçimlerdir ama, duyusal kopyalar (replica) biçiminde görüldüklerinde, tanınabilirler (Langer,1990:158 )

Sanat eserlerinin anlaşmalı bir dilde ifade edilememesi bu duygu biçimlerinin tamamen bir simgede toplanamamasındandır. Bütün simgeler gerçeği düzenlemek için oluşturulmuştur. Simgeler geriye dönüşlüdür. Sanatsal göstergeler ise geriye dönüşlü değildir ve bize hep bir şimdiyi verir.

Bilgi kuramında bilgi, nesne, duyumlar, kavram ve ulamlar sırasıyla oluşur. Nesneyi algılamadan onu kavramlaştırmak mümkün değildir. Sanatsal biçimler bilginin bu ilk basamağına sürekli bir dönüşü içerir. Bu yüzden sanatsal biçimler deneyim olarak tanımlanır. 
Umberto Eco'nun açık yapıt teorisi sanattın bu karakteri üzerine temellenir. Eco'nun sanata yaptığı bu çağdaş katkı, aslında sanatın her zaman kullandığı bir yöntemdir. Deneyim (dünya) olarak sanat eseri, izleyende sürekli yeni duygular uyandıran, karşımda duran şeydir (Eco, 2016)

Sanatın dili gerçekliğin sembole bağlanmış bir vekili değil, gerçekliğin kendisinin bir türevi olarak iş yapmaktadır. Gidimli ve temsili (representational) simgeler arsındaki ayrılık, düz ve sanatsal anlamlar arasındaki ayrıma karşılık olmaz. Temsili simgelerin bir çoğu söylemde yalnız vekildir. Buna karşılık sanatsal simgeler, hiçbir dile çevrilemezler; anlamları büründükleri özel biçime bağlanmıştır her zaman örtülüdürler (implicit) ve herhangi bir yorumla açıklanamazlar (Langer, 1990:157).

Dilsel önermelerin, gerçekliğe uygunluğu, yalnız doğru olup olmadıkları denetlenebilir. Ama sanatsal önermeler böyle bir denetlemeye açı değildir. Burada daha çok bir başarı ve başarısızlık söz konusudur. Aslında sanatsal bir çalışma önermelerin gerçekliğe uygunluğunun doğru olup olmamasından daha çok sanatsal çalışmanın kendi iç işleyişinin başarılı olup olmaması önemlidir denilebilir.

Dil yapıları gerçekliği kavrayabilmek için gerçekliğin sembolik, sigesel biçimlerini yaratmamızda zorunlu olarak başvurduğumuz bir araçtır. Ama gerçeklik anlaşmalı dillerdeki bu simgesel, sembolik biçimlere indirgenemez.

\section{MODERN SANATTA EPISTEMOLOJIKK KRIZZ}

Modern sanatın ve epistemolojinin temel savı olan dünyanın yazı, ses, işaret görüntü temsil edilebileceği, yansıtılabileceği epistemolojik tartışma ve sanatsa arayışlar sırasında bir çıkmaza girer. Söz konusu krizi her ne kadar Tractatus'ta mantıkçı pozitivizmin en dikkate değer örneğini sunmuş olsa da, daha sonraki Felsefî Soruşturmalar adlı yapıtında Wittgenstein tarafından dile getirilmiştir. Bu çalışmasında Wittgenstein, sözcüklerin anlam bakımından temsil etmiş oldukları nesneye tekâbüliyetine vurgu yerine, işlevsel farklılıklarına dikkat çeken "dil oyunları" teorisini geliştirmiştir. Dil oyunları teorisi açısından, sözcük ve cümlelerin tek bir işlevinin olduğunu düşünmek, idealin gerçekten de varolduğu düşüncesini zorunlu hâle getirir ki, Wittgenstein'a göre, sözcüğün belirlenmiş bir anlamının olduğu düşüncesi mitik bir düşünce, göreceliliği reddeden mutlak yalınlık fikri de felsefî bir üst kavramdır. Bu yüzden modern epistemolojinin evrensel dil ve bilgi arayışına karşıt bir şekilde Wittgenstein, dil oyunu terimiyle, "dili; konuşmanın, bir etkinliğin ya da bir yaşam biçiminin parçası" olarak yorumlamak suretiyle, kullanılan dil oyunu çeşitliliği kadar anlamlılık ölçütünün olduğu sonucuna varmıştır. Yaşam tarzlarının ve buna bağlı olarak anlam dünyalarının çokluğu dikkate alındığında, herhangi bir dilin evrensellik vasfını taşıyamayacağı, dolayısıyla gerçekliği temsil edebilme gücüne sahip olamayacağı da açık hale gelecektir. (Küçükalp,2003:92)

Söz konusu kriz ise sanat alanındaki temsil arayışları sırasında üretilen sanat akımları bolluğunda ve her akım/üslup sonucunda yaşanan tatminsizlilk ve başarısılılk hissinde ortaya çıkar. Tüm bu arayış ve çabalar mükemmel, kesin bir temsilin bulunamayacağı düşüncesine sanatçıları sevk edecektir. Bu düşünceleri J. F. Lyotard, İ. Kant'ın sanat ve estetik üzerindeki düşüncelerine dayandırarak şöyle ifade edecektir:

Modern sanatın (buna edebiyatta dahil) dayanağı, avangardların mantığının da aksiyomlarını, yücenin estetiğinde bulduğumu düşünüyorum. Özellikle Kant'a göre, yüce duygusu ki aynı zamanda yücenin duygusudur, güçlü ve anlaşılmaz, ikircikli bir duygudur. Aynı zamanda hem haz hem de acı ihtiva eder. Daha doğrusu burada haz acıdan kaynaklanır. Başkalarının nevroz ya da mazoşizm olarak adlandırdıkları bu çelişki, Augustinus ve Descartes'dan gelen ve Kant'ın da radikal bir biçimde sorgulamadığı özne felsefesi gereği içinde, öznenin yetileri- kavramsallaştırma yetisi ile "gösterme" yetisi- arasında bir çatışma 
olarak gelişir. Bilgi, önce sözcenin anlaş1labilirliği ve sonra da kendisine "uygun düşen" "durumlar"1n deneyden elde edilebilirliğiyle ile koşullanmıştır. Güzelliğin varolama koşulu ise, duyarlık tarafindan, önceden verili hiçbir kavramsal belirlenme olmaksızın iletilen "durum" (sanat yapıtı) karşısında, bu yapıtın uyandırdığı her türlü yarardan bağımsız haz duygusunun ilke olarak evrensel (pratik olarak da hiçbir zaman sağlanamayacak) bir konsensusa çağırıyor olmasidır.

Beğeni böylece kavramsallaştırma kapasitesi ile, kavrama tekabül eden bir nesneyi göz önüne getirme, gösterme yetisi arasında, Kant'ın refleksif yargı dediği yargı türüne yol açan belirlenmemiş, kuralsız bir uyumun, haz kipi altında yaşanabileceğine tanıklık eder. Yüce ise başka bir duygudur. Öncekilerin aksine, imgelem prensipte bile olsa, kavrama uygun düşen bir nesne göstermekte başarısızlığa uğradığında 'yüce' ortaya çıkar. Evren (varolanın bütünlüğ̈̈) ide'sine sahibiz, ama bu ide'yi kendisine bir örnek teşkil edecek, duyumsanabilir bir nesne aracılığıyla görünür kılamıyoruz... dolayısıyla tüm bunlar, yani gösterimleri imkansız ide'ler, gerçekliğe (deneye) ilişkin hiçbir şey bildirmiyorlar, güzellik duygusunu uyandıran, yetilerin özgür uyumunu da, imkansız kılıyorlar; beğeninin oluşumunu ve sabitleşmesini engelliyorlar. Bunların gösterilemez oldukları söylenebilir (Jameson ve diğ., 1994: 51-52).

Lyotard'a göre tüm bir modern sanat bu gösterme kapasitesinden kuşku üzerine kuruludur. Modern sanat bu gösterimi, ancak gösterimin negatif kutbundan yapabilecektir. Sanat deneysellik kulvarına buradan girer.

Peter Bürger “Avangard Kuramı” adlı kitabında gösterdiği gibi öncelikle klasik sanatın bilinçsizce kendine duyduğu güveni eleştiri marifetiyle yıkan avangart yani modern sanat onun kendinden menkul ve insan yaratısı olduğunu gizleyen estetik anlayışını yerle bir ettikten sonra bel bağladığı tekniklerin kültür endüstrisi tarafından içinin boşaltılması ile boşa düşmüştür. Epistemolojik olarak da oldukça kaygan ve belirsiz bir zeminde hareket etmek zorunda kalan modern sanat, gösterimin negatif kutbunu çoğalttıkça bir yöntemler ve üsluplar enflasyonu olacak, tüm bu arayışlar ve çabaların sonucunda sanatsal alanın vardığı yer kendi pratiğine olan bir inançsızlık olacaktır.

\section{EPISTEMOLOJIKK KRIZ VE SANATIN SONU}

Tüm bu akımlar ve arayışlar içinde var olan ve gittikçe belirginleşen bir olgu dikkatimizi çeker. Bu olgu sanat alanında görüntünün geri çekilmesi ve açılan boşluğa metnin yerleşmesidir. Kant'in insan aklında gerçekliği temsil için tespit ettiği iki yetiden biri olan gösterme yetisi paralize olmuş bir durumdadır ve kendi etkinliğin temelinde gösterme, görüntülerle ile temsil etme olan sanatçılar artık görüntünün kendisinden ümit kestiklerinden, görüntü üretmekten vazgeçmişler bunun yerine metni ikame etmenin yollarını aramaya başlamışlardır. Artık sanat dediğimiz şey daha çok bilinci talep etmekte; söze, metne gittikçe artan bir yoğunlukta yer vermektedir. Sanki sanatsal nesneler artık bazı kavramları tartışmamız için üretilmekte, konvansiyonel sanatın o biricik, aşkın nesnesi, metinsel bazı içerikleri tartışmamız için bahane haline gelmektedir.

Brian Wallis sanat ve 'metin' arasında artık son yirmi yılda büyük bir hızla artan değişen rolleri şöyle dile getiriyor: 'Günümüzde konu artık sanat eleştirisinin nasıl en iyi şekilde sanata hizmet verebileceği değil, tam tersine, sanatın eleştirel ve teorik eyleme nasıl dolgun ve zengin bir zemin hazırlayabileceği' diyor. Yani kısaca, eskiden asıl konu olan resimlerin kendileriydi. Ve metin elinden geldiği kadar onların anlaşılmasına çabalayan yardımcı bir öğeydi. Bugün ise, ana konu metinin kendi içeriği ve gelişmesi. Yazarların bütün felsefi ve eleştirel mantıklarını geliştirirken ve sergilerken, örnek olarak söz etmeyi seçtikleri resimler de onların ana prensiplerinin küçük birer illüstrasyonu olma konumuna düşmüşlerdir (Baykam, 1990: 290291). 
Hegel sanattaki bu dönüşümü içsel bir zorunluluk olarak daha önceden tespit etmiş, bu dönüşümün sanatın ölümü olacağını ilan etmişti: Resmin hakikati, konusu olan salt varoluşta değil, salt varoluşun hakikati, onu görünüşe dönüştüren, onda bulunan ve anlamı gizleyen, ayrıntıları ayıklayan, seçen, yeniden biçimlendiren resimdedir. Sanat yapıtı varoluşu 'idealleştirerek' onun hakikatini açığa vurmaktadır. Sanat, salt varoluşu görünüşe dönüştürürken, yeniden biçimlendirirken duyumlanabilir olanı yadsıdı. Ama bu yadsıma yeterli bir yadsıma değildir Hegel için. Çünkü sanat yapıtı duyumlanabilir olanı yadsımak için yine duyumlanabilir bir şey olmak zorundadır. Sanat yapıtı maddesellikten hiçbir zaman tümüyle kurtulamıyor. Böylece o, figür değiştirmesine neden olduğu maddeselliğin tutsağı olmaktan vazgeçemiyor. Bunu tümüyle başardığı an o artık sanat yapıtı olmaktan çıkacaktır (Bumin, 1982:104).

Hegel'e göre sanat bir dil öncesi durumu işaret etmektedir. Sanat kavrama yaklaştıkça ölümünü yaşayacaktır. Ama bu Hegel için üzüntü verici bir durum değildir; çünkü sanat kötü konuşulan bir dildir. Sanatın ölümü aklın doğuşunu müjdelemektedir.

\section{SONUÇ}

Modernitenin gerçeklikle olan ilişkimizde yaratmış olduğu köklü değişim tüm disiplinleri olduğu gibi sanatı da yeniden tanımlamış ve biçimlemiştir. Sanata diğer disiplinlerle verilmiş olan gerçekliğin ele geçirilmesi ve toplumun yeniden inşaası görevi modernitenin bilgi koşulları üzerinde yürütülmek zorundaydı. Modernitenin Kant'ın felsefesinde somutlanan her disiplinin kendi varlık koşullarını gözden geçirmesi ve arındırması için yaptığı zorlama, disiplinin epistemolojik olarak modern bilgi süreçlerine olan problemli ilişkisini oraya koymuştur. Yani sanatın modern bilgi rejimi içindeki yeri bulunmamakta ama sanata bir şekilde bilgi statüsü verilmiştir. Bu durum ise sanatsal alanda krizlere ve sanatın sonu düşüncelerine yol açmıştır.

Sanat alanı, yaşanan bu krizin sonucu olarak modernitenin şafağında kendini 13 dayandırdığı duyum temelli entelektüel varlığını kavramsal lehine aşmaya ya da duyum temelini inkâr ederek ama halen sanatsal alanda kaldığı iddiasını da sürdürerek varlığını devam ettirmektedir. 


\section{KAYNAKÇA}

ALTUĞ, Taylan., 1989, Kant Estetiği, Payel yay., İstanbul

ALTUĞ, Taylan., 1989, Modern Felsefede Metafiziğin Elenmesi ve YolAçtı̆̆ Bilgi Kuramsal Sorunlar, Ege Ünv. Edebiyat Fak. yay.No:50, İzmir

BALCI, Fatih., 2001, “Kendinde Bir Gerçeklik Olarak Fotoğrafın Resim Sanatına Yansıması", Doktora Tezi ,Marmara Üniversitesi

BAYKAM, Bedri., 1990, Post-Modernizm: Hayalet mi yoksa Kaygan Bir Balık mı?,Boyanın Beyni , GİAD(Genç İş Adamları Derneği), İstanbul

BUMIN, Tülin., 1982,Hegel'de Sanatın Ölümü Üzerine Bir Deneme, Seminer Dergisi, Psikoloji, Eğitim, Antropoloji Araştırmasları, Ege Üniversitesi Sosyal Bilimler Fakültesi Yayınları. Haziran, Sayı: 1, İzmir

EAGLETON, Terry., 1994, “Kant'ta İmgesel Olan”,Çev.Hakkı Hünler,Edebiyat Eleştiri

ECO, Umberto., 2016, Açık Yapıt, Çev: Tolga Esmer, Can Yayınları, İstanbul

ERDOĞAN, Bilal., 1990, “Söylem ve Söylen Üstüne”, Mavi Derinlik, Haziran-Temmuz

GENÇ, Adem ve SIPAHİOĞLU Ahmet., 1990, Görsel Algılama, Sergi yay., İzmir

HACIKADİROĞLU, Vehbi., 1985,Bilgi Felsefesi, Metis yay., İstanbul

HARVEY, DAVİD., (2006). Postmodernliğin Durumu: Kültürel Kökenlerin Değişimi, (Çev. Sungur Savran), Metis Yayınları, İstanbul

JAMESON, LYOTARD,HABERMAS,1994,Postmodernizm,Haz: Necmi Zeka, Kiyı yay., İstanbul

JEANNIERE, ABEL., (1994). “Modernite Nedir?” (Çev: Nilgün Tutal-Küçük),

KAHRAMAN, Hasan Bülent., 1995, Sanatsal Gerçeklikler, Olgular ve Öteleri, Yapı Kredi Yay., İstanbul

KAHRAMAN,Yakup., 2017,MODERN EPISTEMOLOJININ TEMEL REFLEKSIYONU OLARAK YÖNTEMSEL DÜŞÜNMENIN ZEMINİ, FLSF (Felsefe ve Sosyal Bilimler Dergisi), Güz, sayı: 24

Kristeller, Paul Oskar., 1965-1980,The Modern System of the Arts. Collected Essays. NJ: Princeton University Press, s 163-227den çevrilmiştir

KÜÇÜKALP, Kasım., MODERN EPİSTEMOLOJİK KRİZ VE POSTMODERN EPİSTEMOLOJI, http://isamveri.org/pdfdrg/D02237/2003_2/2003_2_KUCUKALPK.pdf

LANGER, Suzanne K., 1990, “Sanatsal Anlamlamanın Oluşu”, Yeni Düşün, Çev.Yakup Şahin,

Modernite versus Postmodernite, (Mehmet Küçük), Vadi Yayinları, Ankara

ÖZÜGÜL, Oğuz., 1991, Pozitivizm ya da Mantık Olarak Felsefe, Us yay. İstanbul

PAZ,Octavio.,1994,Şiir ve Modernite, Çev: Nilgün Tutal-Küçük, Modernite versus Postmodernite, Derleyen: Mehmet Küçük, Vadi Yayınları, Ankara

SHINER, Larry., 2004, Sanatın İcadı, Ayrıntı Yayınları, İstanbul

ŞAYLAN, Gencay.,1996, Çağdaş Düşünce Akımları: Postmodernizm,(Ders Notları), TODAİE Yayınları, Ankara 
ŞIMŞEK, İsmail., 2014, ANTIKÇAĞDAN ALMAN İDEALİZMINE; ESTETIK BİR DEĞER OLARAK GÜZELLIK, Atatük Üniversitesi İlahiyat Fakültesi Dergisi, Sayı: 41, Erzurum

TUNALI, İsmail., 1984,Estetik, Cem yay., İstanbul

TUNALI, İsmail.,1983, Ifade Bilimi ve Genel Linguistik Olarak Estetik-B. Croce Estetiğine Giriş, Remzi Kitabevi yay., İstanbul

YILMAZ, Aytekin., 1996, Modernden Postmoderne Siyasal Arayışlar, Vadi Yayınları, Ankara 